\title{
'HOME-GROWNING' INTERNATIONAL RELATIONS IN THE PHILIPPINES: A PRE-THEORISATION
}

\author{
Jeconiah Louis Dreisbach ${ }^{1 *} \&$ Roche Christine C. Angeles ${ }^{2}$ \\ *First author \\ ${ }^{1}$ De La Salle University, Philippines \\ ${ }^{2}$ Helena Z. Benitez School of International Relations and Diplomacy, \\ Philippine Women's University, Philippines \\ (jeconiah_dreisbach@dlsu.edu.ph; 2018t1400@pwu.edu.ph) \\ DOI: https://doi.org/10.22452/jati.vol24no2.6
}

\begin{abstract}
The 'home-grown' turn in international relations (IR) theory emerged to describe original theorising of non-Western IR from the periphery in the periphery. Enthused with the indigenisation movement in the Philippines as our country belongs to the periphery, we delve into pre-theorisations of home growning by applying it to Philippine philosophical, politicohistorical, and psychoanthropological concepts in a schematic analysis. This paper also deliberated the significance of 'paglundag kasama ang wika' (existential immersion with the Filipino language), 'pantayong pananaw' (perspective from-us-for-us, Filipinos), 'pagsasakatutubo mula sa labas' (indigenisation-from-without), and 'pagpapalitaw ng nasa loob' (indigenisation from within) in abstracting nonWestern IR concepts. We contend that Philippine languages play a central role in the Filipino lived experience of the 'international' towards the possibility of contribution to the indigenisation and home-growness of IR as an academic discipline in the Philippines.
\end{abstract}

Keywords: home-grown international relations, indigenisation, Philippine psychology, Filipino philosophy, Southeast Asia

\section{Introduction to Non-Western International Relations}

The idea of non-Western international relations (IR) describes the nature of IR focused only on the West, not going beyond its borders. This produces exclusion from international relations in terms of ideologies, perceptions, and disparities, leaving non-western states' history and situation vague or unknown. Although 
IR should reach further from its British and American roots, it still preserves its influence up to the present day.

International relations became a social science that covers only British and American concepts (Hoffmann, 1977). The lack of presence due to silenced voices of the non-Western world became a serious impediment to the progress of global IR (Acharya, 2000).

This calls for the need to have a global IR with goals focusing on exposing the history, culture, and communication patterns within the Global South to come upon possibilities of preserving non-Western ideas and to make advances that manifest the effort to branch out and promote global IR. What Western scholars think of the non-Western world is that specialists do no more than looking over and watch solely, claiming that critical thinking is not being manifested.

The existing system in IR indeed fails to comprehend the extent of the global world and its potential contributions to its general meaning and assumptions. Global IR offers substantial items to complete the pieces of the puzzles of unaccounted history and diversity that projects differences that western IR has not focused on, if not included. To this end, Acharya and Buzan (2010a) raised three questions about why there is no non-western IR theory and used this to define what global IR is.

First, the core of IR is not open for non-Western states and its main foundation came from the Western perspective. Second, is the characteristic of history, culture, and political aspect being behindhand. Diversity may also be one of the reasons why non-Western IR is being set aside, forgetting shared foundations with Western origins and history. Third, the foundation of nonWestern includes interactional patterns, aboriginal history and culture, and differences of scholars. Although these became questionable and led to squabbles, however, they became a route for open resistance from the nonWestern countries and became an expansive challenge to global discipline.

From that, the term Global International Relations rose. There are six dimensions of Global IR that assumes to start inclusiveness in IR (Acharya, 2014). First, this attempt is not to cover the whole global aspect. But, it is for states to understand each other in respect of diverse identities. Acharya (2014, p. 649) conformed this as 'pluralistic universalism'. Rather than hunt for one single body of history, what should be looked for are the lapsed history, tolerance of diversity, and critical approach in the foundation in IR. Second, is that it should partake in history recognising ideas, think tanks, and intellectual contexts that belong to global IR and can be related to western IR, rather than being an area to be a testing ground of the west. 
Third, IR cannot radiate as a single piece. Global IR tends to include and expand existing theories in western IR instead of superseding and shifting it. It seeks to fill in rather than replace existing knowledge. Global IR gravitates to becoming more flexible and inclusive in the sense of contexts, experiences, and interactions that would soon become or affect theories. This means amassing of assumptions, investigations, and theories which aim to recognise failures by further rethinking of perspectives and focusing, to the prevention of beyond brawl and disharmony. This may be manifested through liberalism and constructivism. Liberalism brings out the idea of good relations and coordination despite differences while constructivism paves the way to creating a firm foundation of ideas and its dissipation.

Fourth, Global IR emphasizes the area studies approach to focus on breaking boundaries in line with land and cultural factors. This is to work on the integration and finding the links of one another to construct a broader picture and extensive substance of international relations. This does not show that regions are divided but rather giving states a space for the exploration of interactivity and harmonic resemblance. Fifth, Global IR should not tolerate the belief of superiority over others, believing that its unique origins and uniformity proves better than another's society, state, or civilisation. It should also not be restricted in narrow borders restricting cultural and political diversity. Lastly, Global IR grasps the perception of operation among non-western societies. This is what Acharya (2014) called agency (p. 650). Western IR opposed that nonwestern IR did not have an agency to perform statecraft in early civilisations. The non-western community's take about the core responsibility of states goes beyond balancing of power and stays away from transnational entrepreneurship conflicts.

Global IR is both ideational and material. This means states can be designed through belief, ideas, with the presence of physical power, as well. Thus, it formulates a wider notion. On the contrary, this may cause complexity in understanding the vast concept of agency in global IR. Agency could also be an avenue for resistance and rejection, considering that it welcomes both Western and non-Western peripheries. It may also be an opportunity to establish a new set of local rules and new approaches to progress and preservation. This also concerns the human conscience in politics (Sikkink, 2013). Its ambition is to comprehend ways to behave between states and non-state actors and figuring out how it can affect the national interests of states.

However, a question arises, what lies behind the absence of non-Western IR? Acharya and Buzan (2010b) laid possibilities on why non-Western IR theory in Asia is not as prevalent as the Western IR (pp. 221-238). The absence of non- 
Western IR can neither be solely reasoned by simply accepting the whole picture of the West's practices and theories, nor non-Western-IR theory lack panoply to be recognised. It is rather because of the lack of institutional assets and Western IR theory's standing in the international arena. The goal is not necessarily to supplant Western IR but to develop it with the expansion consisting of Asian values, extra voices, and deeper and vast rooting, to embrace the variety and representation of different peripheries, whether political, social order, and economic aspects.

Non-Western IR theory may advocate local contexts to establish authentic local ideas for a vast audience. Its omission can be directly connected with the western influence as a fundamental factor which prohibits the presentation of pre-theoretical resources and negligence for participating in the global frame. In connection, the incompatibility of the beliefs, concepts, and ideas of both sides may be another factor of which dissatisfaction arose. The narrowness of western IR causes disparages among Asian scholars and other scholars from different states as well. Thus, non-western IR poses limited applicability in Asia (Acharya \& Buzan, 2007, p. 222). In addition, language and culture may also be a barrier which makes non-western IRT imperceptible, both inside and out. But that is not enough reason to become unrecognised. What is being excluded is the early philosophical discourses rather than the abstraction of Asian international relations.

Moving forward, the reason scattered sources of resources which makes gathering continuous information challenging. Considering that it happens place to place, the activity of institutions, research, scholars, often does not last long. There are also concerns with the possibility of non-Western IR theory in Asia. The difference between Western and non-Western IR and its existence may be misleading, determining whether the source of thought is Western or nonWestern and what constitutes it, respectively. As Acharya and Buzan (2010b) have stated, a global conversation now exists which may complicate distinguishing Western or non-Western (p. 229). Following, IR in the academic field may now be active, but it does not mean that it is being universalised. For it to be normalised, there has to be a correlation between Western and non-Western IR, which not jointly present. The dominance of Western IR still prevails even in local scopes. Subsequently, Asian regionalism differentiates its progression from European regional focus as a subset of non-Western IR.

There is a current presumption that Europe and Asia are today's most important regional focus because they project the quality of regionalised view (Katzenstein, 2005). This was strengthened by Buzan and Wæver (2003), who stated that there are different conditions of understanding international relations in different 
regions. It is also possible that Western IR leans to modernisation while nonWestern IR is still deep-rooted in antiquated practices. The discourse continues between modern and pre-modern. But the important thing is not entirely about which is updated or not. Non-Western IR is not about creating new ones, but by creating its own identity and how it will contribute to the academe of international relations. Its progressive path is heading towards divergence from the West and promoting localisation. However, Asian states need to look back and search for their past to reconnect. Possible sources of non-western IRT were identified to be from the history of classic ideas and experiences. It is how the assessments are being localised and developed to be a non-western thought (Acharya, 2004). After being conceptualised, this could be one of the foundations of non-Western IR as a diverse field. It offers extensive approaches making it sound enough to outwit.

\section{A Southeast Asian Conceptualisation of IR?}

Historical memory and experiences affected the teaching of IR as a discipline in Southeast Asia. In a survey on the teaching contexts of the field in Vietnam, Thailand, Malaysia, Indonesia, and Singapore (Chong \& Hamilton-Hart, 2008), experiences on post-war independence, may it be through revolution, negotiation, and non-colonisation, internal and external military threats, the Cold War, and the interference of the free market contributed to the varying IR pedagogies in the region. The Philippines' stature as the only former Spanish and American colony in Southeast Asia, with a long history of armed struggle against the said colonisers, and on-going ideological conflict between the Government against communist and Moro Islamic revolutionaries may have also affected the way IR is taught in the Philippines. As of this writing, the Philippine International Studies Organization (2016) already spearheaded the international survey on Teaching, Research, and International Policy (TRIP), which compiled the research interests of faculty members who teach international relations in the country. Full data from the said survey are yet to be published by the professional organisation and the Institute for the Theory and Practice of International Relations at the College of William \& Mary, the lead institution of the project.

While it is relevant to understand the influences that formed the kind of teaching of IR that is being taught in the region, part of the continuing struggle of our academic field is the contextualisation of the international experience in our side of the world. Chong (2007) argued that Gramscian hegemony is a factor in the lack of indigenous theorising in Southeast Asia. To come up with counterhegemonic Asian terms and perspectives, scholars of Southeast Asian IR should 
look into the region's indigenous political customs and traditions. Modernisation plays a role in the potential conceptualisation of Southeast Asian IR. It should be pointed out that the former is not just manifestation of imperialism, but it was also the starting point of anti-colonial nationalism in the region. Furthermore, Chong (2007) emphasised that Western scholarship on and indigenous scholarship from the region are connected in the current discourses of the field ( $\mathrm{p}$. 396).

Chong (2007) introduced two ways of dissident theorising from West and Southeast Asian scholars, namely transitional and hybrid theorising. He referred to transitional theorising as models of theorising "where western authors are aware of modernisation-realism and are attempting to establish a bridge towards a more independent framework" (pp. 412-417). Meanwhile, hybrid theorising is the borrowing of Western concepts but is veering away from the dominant IR thoughts of realism. Asians who studied the said Western theories practised theoretical diversity and pursued theoretical innovations by embracing constructivism and postmodernism. Additionally, Chong (2012) suggested to looking onto premodern or accounts of precolonial Southeast Asian historians and philosophers for possible contributions to non-western indigenous forms of IR. A concrete manifestation of early Southeast Asian philosophy that could play a part in conceptualising IR in the region is the concept of 'intersocietal relations' as exhibited in the Malay historical text Sejarah Melayu.

The next part will further discuss the Filipino social science and philosophical concepts that could contribute to the theorisation, or pretheorisation, of Southeast Asian, and eventually, Filipino IR.

\section{‘Home-Growning' IR}

A relatively new concept in the theorisation of non-Western IR is 'homegrowning'. Home-grown international relations is an approach aiming to enrich sources among peripheral states, including those not rooted in the Western dominion. Noticeably, international relations mostly revolve around the West and exclude the Global South. There are significant flaws, lapses, and contradictions to the meaning and concept of 'international relations' (Buzan \& Little, 2000). First, the past and present of IR are Euro-centric and Westerncentric. Second, its origins and concepts do not identify with non-Western concepts, thus excluding them from representation in the arena of international relations. Third, exteriority, a rudimentary system that prevents, if not discourage, the addition of external ideas which will fall under the 'essence' of international relations, end up in a theoretical closure. 
Home-growning and theorising are interrelated in this field (Aydinli \& Biltekin, 2018). There are three types under this, namely: referential home-grown theorising, home-grown alterations, and authentic home-grown theories. Referential home-grown theorising is a method of relying on non-IR thinkers and introducing their inputs in the realm of IR. Home-grown alterations, meanwhile, refers to learning preceding knowledge, which may be from the Western periphery, and using it to broaden and possibly apply to the current local concept of IR. Lastly, authentic home-grown theories refer to concepts developed adjacent to the area of non-western IR attempting to add over as an approach in International relations.

Home-grown theorising in IR has three factors to characterise its sole meaning. Knowledge-wise, it is the use of resources such as history, economic, social and political developments, and literary works. Those are used in the engaging scholarly abstraction of scheme and view, also as instruments to be able to follow transformations fit for the expansion and progress of home-grown IR. Scholar-wise, home-grown IR lacks recognition from the scholarly association. Home-grown theorising should be an avenue for ideas, theories to be paralleled to the local and international sphere. This may be done through the involvement of universities, foundations, think tanks, and scholarly organisations (Kuru, 2018). Lastly, theory-wise, home-grown IR targets the probability of identifying local theories that would define and reshape global IR from its roots.

However, alterations could be done and this poses possible questions about the authenticity of the home-grown idea. But, as long as it includes and emphasises the ideas from scholars who turned in interests in developing local concepts and theories, strengthened and acknowledged by its ingenuity, it can still be considered original and authentic (Aydinli \& Matthews, 2008). Homegrown IR is not about disregarding and replacing existing knowledge. Its primary intention is to widen the field of international relations, making it true to its assumption as being a global field.

\section{Towards a Pre-Theorisation of Filipino IR}

While home-growning is a form of theorising in itself, this paper will not attempt to theorise an indigenous Filipino IR theory adequately. For this paper, we utilised the term pre-theorisation, which Acharya and Buzan (2010a) defined as "elements of thinking that do not necessarily add up to theory in their own right, but which provide possible starting points for doing so", to focus on the texts and Philippine philosophical, historicopolitical, and psycho-anthropological concepts that could be significant in developing a home-grown Filipino IR theory 
(p. 6). Since we rely on non-IR scholars in related academic fields to introduce local concepts in our field, this paper can be considered as a referential homegrown pre-theorisation. Moreover, as we are going to discuss below, Western notions in the social sciences are inevitable in the attempt to develop localised concepts due to the post-colonial nature of the Philippine academia that is why home-grown alterations have to be made to make existing ideas appropriate for analysis in this field.

The paglundag kasama ang wika, which can be directly translated as 'diving along with the Filipino language,' is an immersion to the existential form of knowledge development using the Filipino language. Secondly, pantayong pananaw, which Guillermo (2003) translated as 'a from-us-for-us perspective,' is a leading school of thought in the Philippine social sciences that considers the Philippine nation and its people source for indigenous concepts, and not just subjects of studying. Lastly, Philippine psychology notions on pagsasakatutubo mula sa labas (indigenisation from without) and pagpapalitaw ng nasa loob (indigenisation from within) are possible approaches developed by Virgilio Enriquez (1977) to come up with indigenous concepts and methods. These emerged in the 1960s and 70s during the turn of Philippine academia to the Filipinisation movement and first attempted to search for indigenous social science concepts.

\section{Paglundag Kasama ang Wika: An Existential Immersion to Filipino Experiences through Language}

From the junsui seiken (純粋経験) or pure experience in the Kyoto School of IR (Shimizu, 2018), guoji guanxi (traditional: 國際關係 simplifed: 国际关系) as the translation of international relations in Putonghua (Kavalski, 2018), to the introduction of Sejarah or 'prowess and prestige' by Chong (2012) as a potential Malay contribution to the development of Southeast Asian IR, hegemons and non-hegemons in the international arena are utilising their languages in developing localised concepts of the international (pp. 88-89). Practitioners of Filipino philosophy also see the necessity of employing the Filipino language in philosophising the Filipino ako or self.

Philosophising in the Filipino language was spearheaded by Jesuit priest Roque Ferriols, SJ of the Ateneo de Manila University. His experiential method of philosophising is grounded in the experiences of the Filipino masses (Miranda, 2013). He said that "philosophy must be rooted in life, must come from lived experiences. Philosophy is not just organising concepts. It is about really grappling with living issues". Amongst scholars of Philippine studies, he is known for the signature phrase, "lundagin mo beybe!" which can be translated 
as "go for it, baby!" (Ferriols, 2003). The said line is his introduction to Filipino philosophy. But an individual cannot just dive into philosophy without doing the act of philosophising. Since philosophy in the Philippines should be a lived experience, it cannot be done by an individual alone.

In the intellectual journey of understanding Filipino philosophy, a language is a tool of doing, and in the act of philosophising, we should be employing the languages that are natural to us. Even though there is nothing wrong about speaking a foreign language in philosophising such as English, in the case of the Philippines, the question is can the common person understand what we are saying?

I believe that philosophy is important. Humans have the ability to think rationally because of philosophy. Now, if you are thinking and speaking in English in Manila, and the jeepney drivers, street sweepers, and market vendors do not understand English, you are distancing yourself from the thoughts of the people as they have to use a different language. (Ferriols, cited in Calano, 2013)

For Filipinos to be able to understand their sense of self and the world around them, Ferriols believes that it but to think, speak, and write in the Filipino language and other regional languages of the Philippines. Several terms that have been socially-constructed in the realm of international relations are realpolitik and Weltanschauung, both of which are from the German language. In the TRIP Faculty Survey for IR scholars in France (Cornut \& Dario, 2013) already have high impact factor journals that can be their avenues in discoursing IR using the French language, namely Critique internationale, Cultures et conflits, Études internationales, Politique étrangère, and the Revue française de science politique.

As of this writing, Kritike, Plaridel, Humanities Diliman, Social Science Diliman, Kritika Kultura, Malay, and Daluyan allow Filipino and foreign scholars to submit researches written in the Filipino language. However, none are written for international relations theory. Following the thought of Fr. Ferriols, beyond specialising in international relations theories, we argue that decolonising and home-growing IR in the Philippines would be close to impossible if the scholars do not utilise Philippine languages in developing indigenous IR concepts.

\section{Pantayong Pananaw: Deepening the Conceptual Understanding of Filipino Culture}

Sapitula (2016) described pantayong pananaw (PP) as "tbe most theoretically elaborate articulation of an indigenised social science perspective that offers a 
viable alternative to (Western) positivist social science". It was conceptualised by Zeus Salazar, a historiographer from the University of the Philippines, for the need of a talastasang bayan or national discourse to distinguish historiographies relevant to the formation of Filipino national and cultural identity. This perspective initially identified colonial interactions as the main conflict in Philippine historiography.

The gist of pantayong pananaw is in the internal coherence and bonds of inherent characteristics, values, knowledge, wisdom, goals, customs, proclivities, and experiences of a whole community - a wholeness that is swathed and expressed through a language; in other words, inside a selfdiscoursing culture and civilisation. (Salazar as cited in Hernandez, 2009)

The pangkayo (from-you-to-us) notion is an ethnocentric view of historiography in the Philippines wherein local culture was viewed from the standard of foreign imperialists. To combat this, Filipinos who were educated in Spain, the United States, and Europe responded to these academic atrocities using the language of the colonisers, Spanish and English in this case, and this was referred to as the pangkami (from-us-to-you) perspective. Salazar saw these interactions as a fault as, for him, early scholars were mainly engaged with foreign agents, instead of the locals who are insiders to their own Filipino culture. The current discussions on PP, however, are presently restricted in the academic sphere. Echoing our discussions in the past section, Philippine languages play a major role in the discourses for kaalamang katutubo or indigenous knowledge as these are oriented to the interests of the locals and not of the foreign colonisers (Mendoza, 2007).

Guillermo (2003) set Salazar's existing discourses on PP to Marxist historiography. The latter's arguments on the sole use of local languages for the discourses of national culture was seen as a weakness when Salazar preferred to use the word Tagalog term himagsikan rather than revolución (revolution). For the former, this non-dialectical preference fails to consider the social construction of language as rebolusiyon is already used widely in many Philippine languages. Guillermo (2009) further argued that "etymological meanings of words in their original context matter very little in the process of linguistics borrowing... Consistent with their new linguistic environment, new meanings attach themselves to borrowed terms without regard to their etymological origins".

We concur with the juxtaposition of historical and material dialectics by Guillermo in the decolonisation and indigenisation of social science concepts, most especially in the use of languages. Coinciding with the existential immersion to the Filipino self, a dialectical approach to home-growning IR 
would enjoin the masses and their lived experiences. Filipino scholars have the responsibility to look into the historiographical methods and innovations presented by this approach as an effort to identify primary texts that could help develop potential Filipino contributions to Southeast Asian IR. Schmidt (as cited in Little, 1999) called on the contemporary IR scholars for a historiographical review as the discipline lacked a sense of its history. The potential of PP as a counter-hegemonic discourse in the attempts to indigenise the social sciences in the Philippines presents a promising perspective against the Anglo-American positivistic IR that is currently dominating in our field.

\section{Indigenisation Concepts in Philippine Psychology}

Among all attempts in the indigenisation of social sciences in the country, Philippine psychology, locally known as Sikolohiyang Pilipino (SP), is successful in developing indigenous methods and concepts concerning the Filipino self and culture. As a course in Philippine higher education institutions, it is a requirement for undergraduate students in psychology. The Department of Psychology of the University of the Philippines offers the only Doctor of Philosophy program in Philippine Psychology in the country. Since its inception in the early 1970s, studies on SP have developed indigenous social science concepts (Pe-Pua \& Protacio-Marcelino, 2000; Gastardo-Conaco, 2005), research methods (Enriquez \& Santiago, 1982; Sevilla, 1982), and psychological tests (Guanzon, 1985; Carlota, 1980; Lazo, 1977; Ramos 1977).

As one of the leading movements in the Filipinisation of academia in the country, its strategies in understanding Philippine social realities are similar to Filipino philosophy and pantayong pananaw. Through the use of local languages, scholars can be able to disentangle Filipino characteristics and explain it through the lens of a native Filipino. Some of the identified Filipino national values that are being studied today in SP are hiya (shame), pakikisama (yielding to the leader or majority), utang na loob (gratitude), and bayanihan (togetherness in common effort). Sikolohiyang Pilipino founding father Virgilio Enriquez (1977) mentioned that full use of local languages would avoid the preoccupation with translations and the worry that it cannot be translated into the English language (p. 6).

The two significant tenets of indigenisation in SP are indigenisation-fromwithin and indigenisation-from-without (Clemente, 2011). The latter refers to the contextualisation of a foreign idea, theory, method, or framework to the local context. It involves the modification of the imported notions to fit the culture. It fits very well that it already underwent a process of cultural assimilation. On the other hand, indigenisation from within utilises the cultures that can be found in the 
Philippines in sourcing concepts, methods, and frameworks that scholars of SP consider as substantial to describing Filipino behaviour and experiences.

Enriquez (1977) stated that for the common individual, indigenisation from within might seem boring as it is already given to one's own culture (pp. 13-14). This, however, is the precondition to the survival of the said culture as it continues to evolve in time. The notion of indigenisation only emerged because there is a without, an other, that encouraged it. Instead of demonising the without, it should be seen as a form of modernisation-a modernisation that challenges and pushes existing cultures to progressive development. Having an insider-outsider conflict is essential in conceptualising indigenous concepts as the groups will balance each other's biases and objectivities (Brislin \& Holwill as cited in Pe-Pua, 2006).

We mentioned earlier that SP is a movement that was part of the Filipinisation academia, a manifestation of the cultural turn of the social sciences and humanities in the 1970s. Madeline Sta. Maria was the first Filipino psychologist to criticise the academic nature of SP as its early proponents failed to define culture, which is necessary for the attempts to indigenise the social sciences (Demeterio, Liwanag, \& Ruiz, 2017). Due to the political nature of SP, Sta. Maria argued that the crisis of indigenisation of psychology in the Philippines has not ended as a political movement is not a scientific discipline. She further stated that the "indigenization crisis was a crisis of scientific discipline, it was a crisis of a discipline that was Western" (p. 61).

We partly agree and disagree on the notions of Sta. Maria on the indigenisation of Philippine psychology. We agree that SP is political in nature, but disagree that it cannot be part of the indigenisation crisis that social science is currently undergoing. The attempt to decolonise and indigenise the social sciences from the dominant Western hegemonic theories and frameworks is a political war of competing discourses.

Completing these discourses are our schematic application of the typologies of home-grown theorising in IR to the cultural flows of indigenisation of Philippine psychology that was first introduced by Villegas (1977, p. 15), as shown in Figure 1. Several IR studies such as Valbjørn (2006) and Van Veeren (2009) claimed that the academic discipline underwent a cultural turn that took into consideration humanity's cultural practices and identities in the analysis of international phenomena. However, Reus-Smit (2018) argued that IR failed to incorporate contemporary notions on culture, and there is a need for this to be rectified as culture may have an influential role in understanding global politics. The field's current conceptions of culture are currently stuck in the 1930s and 1950s. Realists still study conflict groups in cultural units such as nation-states. 
Constructivism, while promising in their presentation of culture, still looks at collective international norms and mentalities of sovereign nations.

Figure 1: A Schematic Application of the Typologies of Home-grown

Theorising in International Relations to the Cultural Flows of Indigenisation in Philippine Psychology

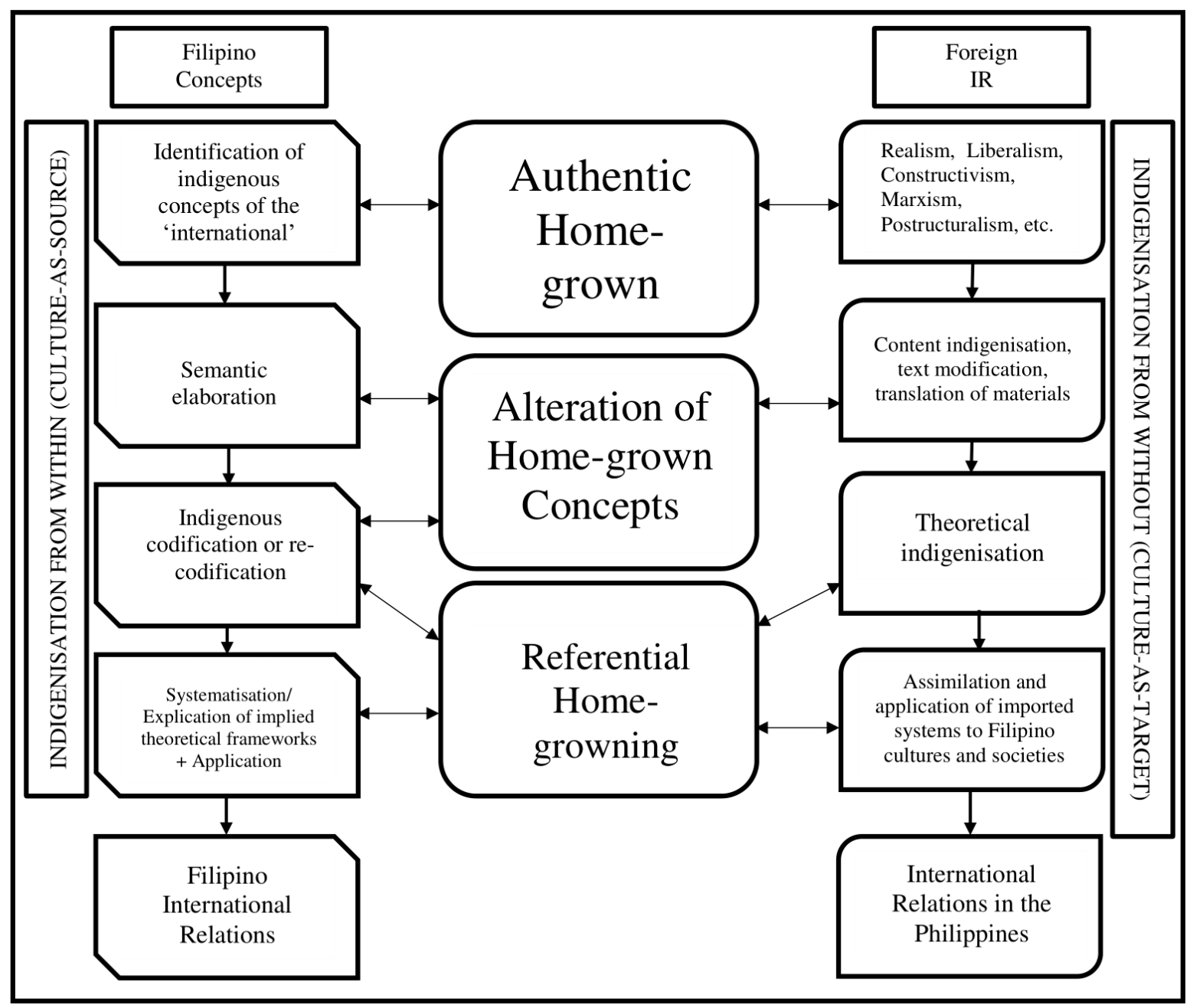

(Source: Authors' own adaptation.)

In our pre-theorisation of Filipino IR, we define culture as a collectivity of individuals with identical ethnolinguistic backgrounds. Existing Philippine cultures can be both sources and targets of global international relations in the attempt to indigenise and decolonise the discipline. For this paper, we would like 
to make a distinction between Filipino IR and IR in the Philippines. The former would emerge from existing notions of the international that may have been lived and experienced by the Filipino people. The latter, on the other hand, is simply an application of existing foreign IR theories, may it be from the Global North or South, in the Philippines.

Filipino scholars studying local cultures need to identify indigenous concepts of the international by means of reviewing the literature, both academic and fictional. Following the identification of potential concepts, there should be verification and reflection of lived experiences by the people through semantic elaboration. This alteration process of the international should resume the process of codification until concrete concepts, theories, and frameworks are systematised and explicated. An indication of the emergence of a home-grown Filipino IR is its application to global international relations theory.

We consider existing foreign, including Western and non-Western, IR theories as authentic home-grown concepts as they have definite origins. As long been practised, these can be applied to the Philippines through content indigenisation, text indigenisation, and the publication of reading materials in the local languages. It can then undergo a process of theoretic indigenisation wherein these foreign concepts will be applied to the sensibilities of Filipino cultures and societies. A demonstration of its successful application is its cultural assimilation.

\section{Conclusion}

This paper is a reaffirmation of the point-of-view of Chong (2007) in conceptualising Southeast Asian international relations: democratising the academic discipline in the region and universalising local concepts and practices (p. 420). By attempting to pre-theorise Filipino international relations in the prestigious journal, this will potentially open healthy discourses on the status of our academic field in the Philippines. Moreover, our emphasis on the use of Philippine local languages is an encouragement not just to continue the tradition of the nationalist movement to intellectualise our languages.

\section{Acknowledgements}

An earlier version of this paper was presented in the Fifth International Conference on Philippine and Asian Studies at De La Salle Lipa in May 2019. The authors thank the valuable comments and suggestions of the conference participants and co-presenters, as well as the reviewers of the JATI - Journal of Southeast Asian Studies, that made the publication of this paper successful. 


\section{References}

Acharya, A. (2000). The Quest for Identity: International Relations of Southeast Asia. Singapore: Oxford University Press.

Acharya, A. (2004) How Ideas Spread: Whose Norms Matter? Norm Localization and Institutional Change in Asian Regionalism. International Organization, 58(2), 239-275.

Acharya, A. (2014). Global International Relations (IR) and Regional Worlds: A New Agenda for International Studies. International Studies Quarterly, 58(4), 647-659.

Acharya, A., \& Buzan, B. (2007). Why is There No Non-Western International Relations Theory? An Introduction. International Relations of the AsiaPacific, 7(3), 287-312.

Acharya, A., \& Buzan, B. (2010a). Why is There No Non-Western International Relations Theory? An Introduction. In A. Acharya \& B. Buzan (Eds.), Non-Western International Relations Theory: Reflections on and Beyond Asia (pp. 1-25). Oxfordshire: Routledge.

Acharya, A., \& Buzan, B. (2010b). Conclusion: On the Possibility of a NonWestern International Relations Theory. In A. Acharya \& B. Buzan (Eds.), Non-Western International Relations Theory: Reflections on and Beyond Asia (pp. 221-238). Oxfordshire: Routledge.

Aydınli, E., \& Biltekin, C. (2018). Widening the World of IR: A Typology of Homegrown Theorizing. All Azimuth, 7(1), 45-68.

Aydınli, E., \& Matthews, J. (2008). Periphery Theorizing for a Truly Internationalised Discipline: Spinning IR Theory of Anatolia. Review of International Studies, 34(4), 693-712.

Buzan, B., \& Little, R. (2000). International Systems in World History. New York: Oxford University Press.

Buzan, B. and Wæver, O. (2003). Regions and Powers. Cambridge: Cambridge University Press.

Calano, M. J. T. (2013). Patakarang Pilosopikal: Pambungad sa Pamimilosopiya ni Roque Ferriols. Scientia: The Research Journal of the College of Arts and Sciences of San Beda College, 2(1), 98-113.

Carlota, A. J. (1980). Research Trends in Psychological Testing. In A. Carlota \& L. Lazo (Eds.), Psychological Measurement: A Book of Readings (pp. 31-47). Quezon City: U.P. Psychology Foundation.

Chong, A. (2007). Southeast Asia: Theory Between Modernization and Tradition. International Relations of the Asia-Pacific, 7(3), 391-425. 
Chong, A. (2012). Premodern Southeast Asia as a Guide to International Relations between Peoples: Prowess and Prestige in "Intersocietal Relations" in the Sejarah Melayu. Alternatives, 37(2), 87-105.

Chong, A., \& Hamilton-Hart, N. (2008). Teaching International Relations in Southeast Asia: Historical Memory, Academic Context, and Politics - An Introduction. International Relations of the Asia-Pacific, 9(1), 1-18.

Clemente, J. A. (2011). An Empirical Analysis of Research Trends in the Philippine Journal of Psychology: Implications for Sikolohiyang Pilipino. Philippine Social Science Review, 63(1), 1-33.

Cornut, J., \& Dario, B. (2013). French IR Scholars in the 2011 Trip Survey. Revue française de science politique, 63(2), 97-128.

Demeterio, F. P. A., Liwanag, L. A. L., \& Ruiz, P. J. A. (2017). Si Madelene Sta. Maria at ang Sikolohiyang Pilipino: Pakikipanayam sa isa sa mga Kaunaunahang Iskolar na Bumatikos sa Nasabing Intelektuwal na Kilusan. Kritike, 11(1), 48-69.

Enriquez, V. G. (1977). Filipino Psychology in the Third World. Philippine Journal of sychology, 10(1), 3-18.

Enriquez, V. G., \& Santiago, C. (1982). Tungo sa Makapilipinonng Pananaliksik. In R. Pe-Pua (Ed.), Sikolohiyang Pilipino: Teorya, Metodo at Gamit (pp. 155160). Quezon City: University of the Philippines Press.

Ferriols, R. J. (2003). Sapagkat ang Pilosopiya ay Ginagawa. Pilosopo Tasyo: A Network of Philosophy Faculty in the Philippines. Retrieved May, 5, 2019, from http://pilosopotasyo.tripod.com/una.html

Gastardo-Conaco, M. C. (2005). The Development of a Filipino Indigenous Psychology. Philippine Journal of Psychology, 38(2), 1-17.

Guanzon, M. C. (1985). Paggamit ng panukat sikolohikal sa Pilipinas: Kalagayan at mga isyu. In A. Aganon \& M. David (Eds.), Sikolohiyang Pilipino: Isyu, pananaw at kaalaman (pp. 341-370). Manila: National Book Store.

Guillermo, R. (2003). Exposition, Critique, and New Directions for Pantayong Pananaw. Kyoto Review of Southeast Asia, 3. Retrieved December 24, 2019, from https://kyotoreview.org/issue-3-nations-and-stories/expositioncritique-and-new-directions-for-pantayong-pananaw/

Guillermo, R. (2009). Pantayong Pananaw and the History of Philippine Political Concepts. Kritika Kultura, 13, 107-116.

Hernandez, J. R. B. (2009). Ang Pandaigdigang Pananaw ng Pantayong Pananaw. Kritika Kultura, 13, 136-144.

Hoffmann, S. (1977). An American Social Science: International Relations. Daedalus, 106(3), 41-60. 
Katzenstein, P. (2005). A World of Regions: Asia and Europe in the American Imperium. Ithaca: Cornell University Press.

Kavalski, E. (2018). The Guanxi of Relational International Affairs. Chinese Political Science Review, 3(3), 233-251.

Kuru, D. (2018). Homegrown Theorizing: Knowledge, Scholars, Theory. All Azimuth: A Journal of Foreign Policy and Peace, 7(1), 69-86.

Lazo, L. (1977). Psychological Testing in Schools: An Assessment. Philippine Journal of Psychology, 11(1), 23-27.

Little, R. (1999). Historiography and International Relations. Review of International Studies, 25(2), 291-299.

Mendoza, S. L. L. (2007). Theoretical Advances in the Discourse of Indigenization. In A. Navarro \& F. Lagbao-Bolante (Eds.), Mga Babasahin sa Agham Panlipunang Pilipino: Sikolohiyang Pilipino, Pilipinolohiya, at Pantayong Pananaw (pp. 241-297). Quezon City: C\&E Publishing.

Miranda, P. V. (2013, December 11). Ferriols Retires from Teaching. The Guidon. Retrieved May 5, 2019, from http://www.theguidon.com/1112/main/2013/12/ferriols-retires-fromteaching/

Pe-Pua, R. (2006). From Decolonizing Psychology to the Development of a CrossIndigenous Perspective in Methodology: The Philippine Experience. In U. Kim, Yang K.S., \& Hwang K. K. (Eds.), Indigenous and Cultural Psychology: Understanding People in Context (pp. 109-137). Boston, MA: Springer.

Pe-Pua, R., \& Protacio-Marcelino, E. (2000). Sikolohiyang Pilipino (Filipino Psychology): A legacy of Virgilio G. Enriquez. Asian Journal of Social Psychology, 3(1), 49-71.

Philippine International Studies Organization. (2016). PHISO is the Country Partner of 2017 TRIP Faculty Survey. Retrieved May 5, 2019, from https://phiso.org/2016/12/26/phiso-is-the-country-partner-of-2017-tripfaculty-survey/

Ramos, E. (1977). Assessment of Psychological Testing in the Philippines: Focus on Industries and National Education. Philippine Journal of Psychology, 11(1), 19-22.

Reus-Smit, C. (2018). On Cultural Diversity: International Theory in a World of Difference. Cambridge, UK: Cambridge University Press.

Sapitula, M. V. (2016). Pook at Paninindigan: A Critical Appraisal of Pantayong Pananaw. Harvard-Yenching Institute. Retrieved May 6, 2019, from https://harvard-yenching.org/features/pook-paninindigan-criticalappraisal-pantayong-pananaw 
Sevilla, J. C. (1982). Indigenous Research Methods: Evaluating First Returns. In R. Pe-Pua (Ed.), Sikolohiyang Pilipino: Teorya, Metodo at Gamit (pp. 221-232). Quezon City: University of the Philippines Press.

Shimizu, K. (2018). Do Time and Language Matter in IR? Nishida Kitaro's NonWestern Discourse of Philosophy and Politics. The Korean Journal of International Studies, 16(1), 99-119.

Sikkink, K. (2013, April 30). What is Agentic Constructivism? Paper presented at the Colloquium on The Future of Constructivist Research in International Relations, Oxford University, Oxford, United Kingdom.

Valbjørn, M. (2006). Before, During and After the Cultural Turn: A 'Baedeker' to IR's Cultural Journey. International Review of Sociology, 18(1), 55-82.

Van Veeren, E. (2009). The 'Cultural Turn' in International Relations: Making Sense of World Politics. E-International Relations. Retrieved May 7, 2019, from https://www.e-ir.info/2009/05/10/the-\%E2\%80\%98culturalturn $\%$ E2\% $80 \% 99$-in-international-relations-making-sense-of-worldpolitic

Date Received: 6 Jun 2019 Date of Acceptance: 15 December 2019 